Article

\title{
Anthropogenic Impacts on Coral Reef Harpacticoid Copepods
}

\author{
Marina Siqueira Barroso ${ }^{1}$, Brenno J. da Silva ${ }^{2}{ }^{\circledR}$, Manuel J. Flores Montes ${ }^{2}$ \\ and Paulo J. P. Santos $1, *$ (i) \\ 1 Departamento de Zoologia and Programa de Pós-Graduação em Biologia Animal, Centro de Biociências, \\ Universidade Federal de Pernambuco, Avenida Professor Morais Rêgo s/n, Cidade Universitária, \\ Recife 50670-420, Brazil; marinadesiqueira@hotmail.com \\ 2 Departamento de Oceanografia, Centro de Ciências Exatas e da Terra, Universidade Federal de Pernambuco, \\ Avenida Arquitetura s/n, Cidade Universitária, Recife 50740-550, Brazil; \\ brennojanuario@gmail.com (B.J.d.S.); manuel@ufpe.br (M.J.F.M.) \\ * Correspondence: pjp.santos@gmail.com
}

Received: 20 February 2018; Accepted: 30 April 2018; Published: 4 May 2018

\begin{abstract}
The number of studies demonstrating the susceptibility of benthic reef communities to anthropogenic impacts is growing. However, for some of the components of reef fauna, such as meiobenthic harpacticoid copepods, information is still lacking. Here, different diversity and taxonomic distinctness indexes and multivariate analyses were used to test whether the assemblage of harpacticoid copepods colonizing Artificial Substrate Units (ASUs) is an appropriate tool for the identification of reefs subjected to different levels of anthropogenic pressure. Furthermore, we also evaluate if diffused, persistent, anthropogenic impacts generate the homogenization and simplification of Harpacticoida assemblages. Six reefs were organized into two groups along the coast, depending on their proximity to very large urban centers. ASUs were used for meiofauna colonization and, for each reef, 320 Harpacticoida individuals were separated for identification at the species level. Abiotic parameters were analyzed, and significant differences were found between the two groups of reefs, with an increase in dissolved inorganic nutrients found in areas near large urban centers. Both the multivariate analyses and the indexes of diversity showed a clear separation between the reefs closer to the urban zones and those further away, as a response to the anthropogenic pressure. As hypothesized, in the impacted reef areas, there was a strong simplification and homogenization of the harpacticoid copepod assemblages. However, the results of the indexes, based on taxonomic distinctness, suggest that there was no phylogenetic signal of anthropogenic impact on coral reef harpacticoid copepods.
\end{abstract}

Keywords: meiobenthos; diversity indices; phytal; urban pollution

\section{Introduction}

Anthropogenic impact is changing our planet. Human pressure continues to affect the ability of ecosystems to provide essential services [1]. Understanding how ecosystems and ecological communities respond to global changes is one of the main challenges faced by ecologists [2]. As a result, impact/ environmental quality indicators and organism models are sought after and tested in the most diverse marine ecosystems [2].

On a global scale, coastal, estuarine and transition ecosystems are strongly impacted by human activities [3], such as overfishing, eutrophication, tourism, and engineering works [4,5]. This is due to the development of human populations historically being concentrated in coastal areas, causing profound alterations in these environments [6]. Recently, studies have highlighted the negative 
effects of anthropogenic disturbances on coastal benthic communities, such as increased seawater temperatures in tropical environments [7], ocean acidification [8,9], and diffused source pollution [10]. In addition, during the last few decades, scientific literature has pointed out that human activities are not random in their negative and positive impacts on the communities in question [11-14]. Evidence shows that most species show a decline in population size when subjected to anthropogenic impacts ("losers"), and are being replaced by a much smaller number of resistant/opportunistic species that thrive in environments impacted by human activity ("winners") [15]. The result is a homogenization of communities, with less diversity on both regional and global scales [15].

The only reef formations in the southwest Atlantic Ocean are found in Brazil, and they are among the most prominent marine ecosystems in tropical Brazil. Furthermore, due to their distribution along $3000 \mathrm{~km}$ of coastline, they are found within some of the most biologically diverse marine ecosystems [16-18]. In addition to their use as breeding and nursery areas, they shelter and feed a huge variety of marine organisms [19]. Despite the importance of goods and ecological services provided by reef systems, such as fishery production and reef tourism $[19,20]$, the extension of coastal reefs in northeast Brazil shows signs of being strongly impacted as a result of uncontrolled urban development, tourist activities, and the eutrophication of water in association with pollution [16-18,21]. Furthermore, in zones located closest to large urban centers, it has been found that anthropogenic impacts are more aggravated, with an increase in sedimentation due to the removal of fragments from the Atlantic Forest and an increase in the release of effluents, such as waste, which appear to be the main factors responsible for this alarming situation [22].

The use of artificial substrates units (ASU) in studies evaluating environmental quality has been recommended in recent years as a potential solution to bypass the effects of natural variation in substrate structure or characteristics [23-26]. This reduces the heterogeneity between replicates of the same association and, as a result, reduces the effort needed to detect impacts. For ASUs previously tested in studies with meiofauna, abundance values of more than 3000 individuals per ASU were usually found (e.g., References [23,25]), which allows ASUs to be implemented as appropriate tools in environmental monitoring studies.

Harpacticoid copepods have a high diversity in phytal environments [27], fast life cycles, a large ecological importance in the transfer of energy to higher trophic levels [28,29], and are sensitive to anthropogenic impacts [30,31]. These characteristics make the group a very good indicator in studies of environmental impacts, particularly when associated with artificial substrates [32].

In 1995, Warwick and Clarke [33] proposed that the phylogenetic structure of a community is clearly important in environmental impact studies. However, the majority of studies investigating aspects of the application and interpretation of results from taxonomic distinction indexes in benthic communities (e.g., References [34-41]) were performed in estuarine areas.

This study evaluates the use of different diversity and taxonomic distinctness indexes and multivariate analyses to test whether assemblages of Harpacticoida colonizing Artificial Substrate Units (ASUs) are an appropriate tool to identify reefs under different levels of anthropogenic pressure. Furthermore, considering that as a result of human activities, most species tend to decline (i.e., losers), and are replaced by a few non-randomly distributed taxa (i.e., winners) [15], we also evaluate if diffused, persistent, anthropogenic impacts associated with large urban centers generate the homogenization and simplification of Harpacticoida assemblages in coral reefs.

\section{Materials and Methods}

The coastal reefs included in this study were divided into two groups: the Impacted Areas (Rio Doce, Piedade and Paiva), due to their location in the metropolitan region of Recife (which has over four million inhabitants with an average density of over 1000 inhabitants $/ \mathrm{km}^{2}$, and is the region subjected to the outflow of several highly polluted rivers), and the Control Areas which were distant from large urban centers (Porto de Galinhas, Serrambi and Tamandaré). This allowed for the comparison of environmental conditions and meiofauna compositions between the two groups (Figure 1). 


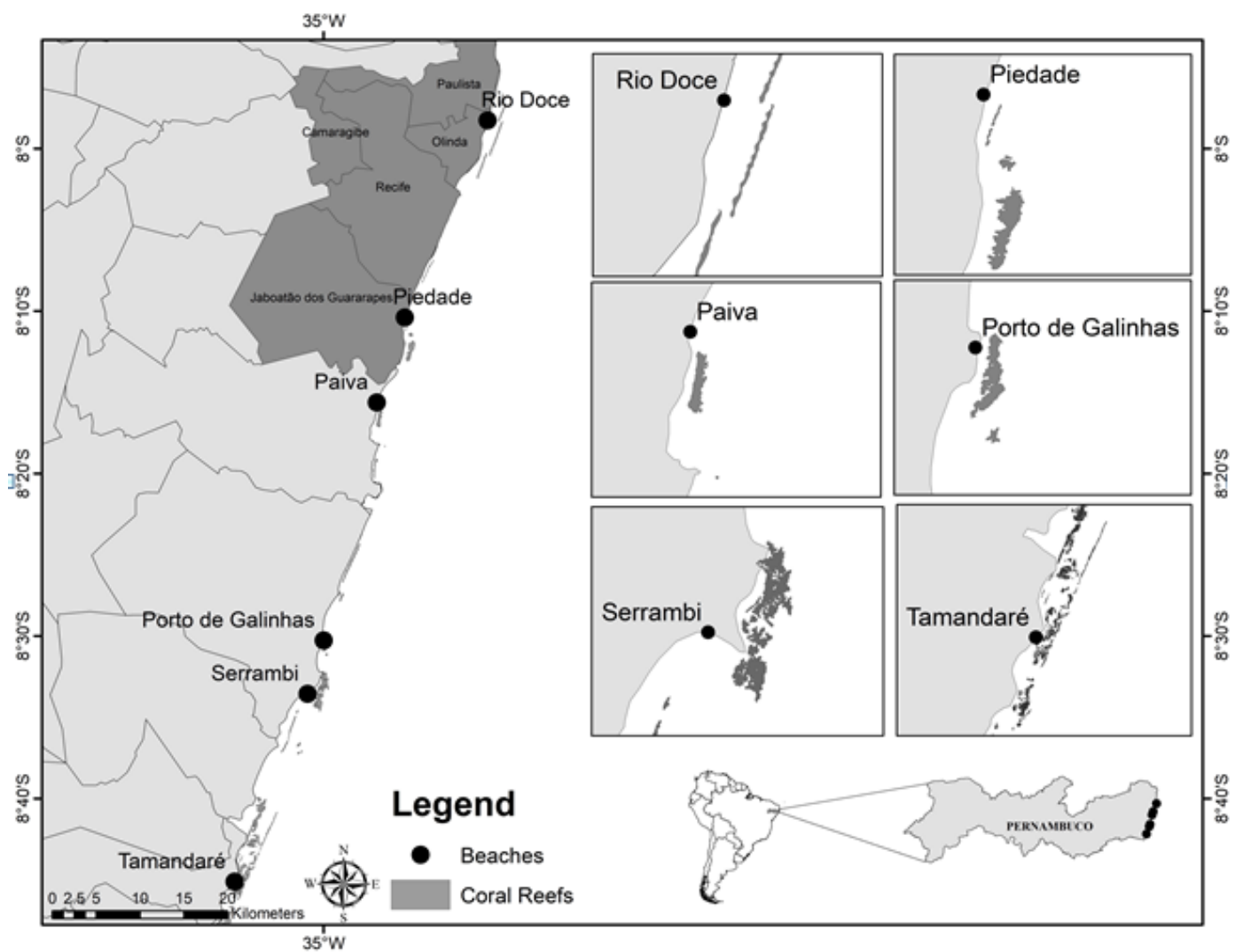

Figure 1. Map of the coastal region of Pernambuco, Brazil, indicating the experimental reef areas. Dark grey areas indicate an average density above 1000 inhabitants $/ \mathrm{km}^{2}$.

A portion of reef was selected for the experiment implantation in each reef. Each portion selected was the area of reef furthest from the edge of the beach and reasonably well protected from humans bathing, so as to preserve the integrity of the experiment. Since access to these areas depends on tide levels, low tides were selected $(0.1$ to $0.4 \mathrm{~m})$ as the most adequate times for the implantation procedure and the collection of ASUs, as well as for the analysis of abiotic parameter samples.

During the experiment implantation and removal of the ASUs, temperature and salinity were measured in situ with a thermometer and an optical refractometer (Instrutemp ITREF 10) respectively, and parallel seawater samples were collected using an oceanographic Niskin bottle for chemical analyses at the Chemical Oceanography Laboratory (LOQuim). The dissolved inorganic nutrients were measured by colorimetric methods using a spectrophotometer (Cary 100). Ammonium $\left(\mathrm{NH}_{3}+\mathrm{NH}_{4}{ }^{+}\right)$levels were measured using the blue indophenol method described by Grasshoff et al. [42]. Nitrate $\left(\mathrm{NO}^{3-}\right)$ and nitrite $\left(\mathrm{NO}^{2-}\right)$ levels were measured using the sulfanilamide $\left(\mathrm{C}_{6} \mathrm{H}_{8} \mathrm{~N}_{2} \mathrm{O}_{2} \mathrm{~S}\right)$ method [43]. Dissolved inorganic nitrogen (DIN) was represented by the sum of $\mathrm{NO}^{3-}, \mathrm{NO}^{2-}, \mathrm{NH}_{3}$ and $\mathrm{NH}_{4}{ }^{+}$concentrations.

Concentrations of silicate $\left(\mathrm{SiO}_{2}\right)$ and dissolved inorganic phosphorus (DIP) were determined based on the production of a blue compound when orthosilicic acid and phosphate ions $\left(\mathrm{PO}_{4}{ }^{3-}\right)$, reacted with acidified molybdate [42]. Particulate materials in suspension (PMS) were quantified by a gravimetric method, determined by Strickland and Parsons [42]. Dissolved oxygen (DO) was analyzed following a modified Winkler method [43], and its saturation (DO\%) was calculated according to the International Oceanographic Tables [44].

Total Alcalinity (TA) samples were poisoned with mercury chloride $\left(\mathrm{HgCl}_{2}\right)$ to prevent biological alterations, and measurements were taken following Dickson et al.'s [45] methodology, represented by its titration with hydrogen chloride $(\mathrm{HCl})$ at $0.1 \mathrm{~N}$. Certified Reference Materials $(\mathrm{CRM})$ provided by Andrew Dickson (Scripps Institutions of Oceanography, San Diego, CA, USA) were used for the calibration and validation of the values. Simultaneously, $\mathrm{pH}$ was measured using a Thermo Scientific ${ }^{\mathrm{TM}} \mathrm{pH}$ meter Star A211. 
The ASUs selected for this study were rectangles of $10 \times 5 \mathrm{~cm}$ synthetic grass that adequately mimic the turf algae environment and have been used in experimental laboratory studies investigating the anthropogenic impacts on meiofauna communities in reef environments $[9,46]$.

The artificial turfs were secured with silk cords using $1.6 \mathrm{~mm}$ thick nylon string, minimizing the chances of breaking away and loss of the structures, due to wave action. The cords were tied to the infralittoral zone (1-2 m depth) of the reef with 10 ASU replicates placed in each area. Colonization time was standardized as one month for all reef areas. The decision of experimental duration was based on the elevated temperatures in northeast Brazil (commonly above $22{ }^{\circ} \mathrm{C}$ ), during which it is expected that the life cycle of meiofaunal organisms allow the occurrence of two to three generations of initial colonizers (see for example, the model for harpacticoid copepods [47]).

Four replicates were used from each area, following the visual evaluation of the ASUs' integrities post-experiment (i.e., the artificial turf was visually, completely covered by colonizers, and nylon strings and silk cords were unbroken). In areas where more replicates were undamaged, four more were randomly selected. The ASUs were added to plastic pots, fixed in $4 \%$ formaldehyde solution, and taken to the laboratory where meiofauna were extracted from the substrate and washed successively with running, filtered water over sieves with mesh size $0.5 \mathrm{~mm}$ (to remove the macrofauna) and $0.045 \mathrm{~mm}$ (to retain the meiofauna).

After the collection of the colonized ASUs and the separation of the meiofauna, the first 80 harpacticoid copepod individuals were removed from each replicate (320 per reef) and were placed in Eppendorf microtubes with $70 \%$ alcohol for later analysis. The sample size followed published studies on anthropogenic impacts affecting harpacticoid species colonizing ASUs: Costa et al. [32] (5 replicates per estuary $\times 30$ individuals per replicate); Sarmento et al. [48] (4 replicates per treatment $\times 60$ individuals per replicate). The individuals were fixed on slides, and the identification of species was accomplished through the observation of the entire animal under an optic microscope, based on taxonomic keys and descriptions [49-51], as well as other publications. Since total counts of harpacticoid copepods were available for all replicate samples, proportions of identified species were adjusted to densities for analysis. A list with harpacticoid copepod species found in reef regions in the state of Pernambuco was created using identification data from Sarmento and Santos [31], Barreto [52] and Nascimento [53]. This list was considered as a regional list, to which all lists from the reefs included in this study could be compared in order to estimate the taxonomic distinction indexes: taxonomic diversity (Delta), taxonomic distance (Delta*), average taxonomic distance (Delta+), total taxonomic distance (sDelta+), and the variation of taxonomic distance (Lambda+) $[33,35,54]$. The regional list was organized under Linnean classifications considering five levels of taxonomic hierarchies (species, genus, family, sub-order and order). The Delta and Delta* indexes were calculated based on the untransformed abundance data. The Delta+, sDelta+ and Lambda+ indexes were calculated based on the presence/absence of species in coastal reefs. Shannon-Wiener diversity $\left(\mathrm{H}^{\prime}\right.$, using a log of base 2), Margalef's diversity, Pielou's evenness ( $\left.\mathrm{J}^{\prime}\right)$, and species richness indexes were also calculated. The mathematical models followed Clarke and Warwick [33,54] and Salas et al.'s [55] recommendations, and PRIMER ${ }^{\circledR}$ software (Plymouth Routines in Multivariate Ecological Researches) packages v6 and PERMANOVA were used for the calculations.

A nested PERMANOVA analysis was performed to evaluate the differences between the two groups of areas (factor: Impact) and between reef areas (factor: Reef) within impact levels for multivariate community structure. To measure the similarity between colonizer fauna samples from the ASUs, the Bray-Curtis index was used. Non-metric multi-dimensional scaling (NMDS) was used to represent the Bray-Curtis matrix graphically in a two-axis space. A similarity percentage (SIMPER) analysis was applied to determine which groups were responsible for the dissimilarities between the two groups of areas (factor: Impact) and PERMDISP was used to test if there were differences in multivariate dispersion. A nested PERMANOVA was also used to evaluate the differences between the two groups of areas for abiotic parameters. To measure the distance between samples considering environmental descriptive parameters, the Euclidean distance was used. Mann-Whitney tests were also used to compare the two groups of areas considering individual abiotic parameters. Student's t-tests were used to compare the two groups of areas in relation to their univariate indexes. In the absence of 
the homogeneity of variances, a PERMANOVA was used (which, in this case, is reduced to an ANOVA whose significance is tested by permutations).

Multivariate analyses followed Anderson [56], MacArdle and Anderson [57], and Clarke and Warwick's [58] recommendations, whereas parametric univariate analyses followed application suggestions by Zar [59]. Statistical analyses were performed using PRIMER ${ }^{\circledR}$ software packages v6 and PERMANOVA, and using the STATISTICA v12 program. A significance level of 5\% was used for all analyses.

\section{Results}

The results of the physical-chemical characterization of the environment at the time of the experiment implantation and collection of the colonized ASUs can be found in Table 1. Considering the abiotic variables, the control and impacted areas were compared using a nested PERMANOVA analysis, and results indicated a significant difference (Pseudo- $\mathrm{F}=1.999 ; p<0.001$ ). The reefs nested within each area were not significantly different from each other (Pseudo-F $=1.450 ; p=0.227$ ).

In the control areas, $\mathrm{SiO}_{2}$ was represented by a mean concentration of $6.67 \mu \mathrm{mol} \mathrm{L}{ }^{-1}$ and, in the impacted areas, $25.15 \mu \mathrm{mol} \mathrm{L}^{-1}$. The dissolved inorganic nutrients (DIN) presented a mean of $2.26 \mu \mathrm{mol}$ $\mathrm{L}^{-1}$ and $8.41 \mu \mathrm{mol} \mathrm{L}^{-1}$, and dissolved inorganic phosphorus (DIP) presented mean values of $0.19 \mu \mathrm{mol}$ $\mathrm{L}^{-1}$ and $0.57 \mu \mathrm{mol} \mathrm{L}^{-1}$ in the control and impacted areas, respectively.

The $\mathrm{SiO}_{2}$, DIN and DIP were represented by significantly higher concentrations in impacted areas when compared to the control areas ( $p=0.008 ; p=0.003 ; p=0.04$, respectively). DO $\%$, salinity, PMS, $\mathrm{pH}$ and TA were not significantly different between the impacted and control areas. Significant differences $(p=0.01)$ between these groups were found for temperature $\left({ }^{\circ} \mathrm{C}\right)$, with a mean of $28^{\circ} \mathrm{C}$ for impacted, and of $29.86^{\circ} \mathrm{C}$ for control areas.

Table 1. Mean values ( \pm standard deviation) of the environmental variables according to the study areas: PMS $\left(\mathrm{mg} \mathrm{L}^{-1}\right)$, salinity, temperature $\left({ }^{\circ} \mathrm{C}\right), \mathrm{DO}(\%), \mathrm{pH}, \mathrm{TA}\left(\mu \mathrm{mol} \mathrm{L}{ }^{-1}\right), \mathrm{SiO}_{2}\left(\mu \mathrm{mol} \mathrm{L}{ }^{-1}\right), \mathrm{DIN}$ $(\mu \mathrm{mol} \mathrm{L}-1)$, and DIP $(\mu \mathrm{mol} \mathrm{L}-1)$.

\begin{tabular}{cccccccccc}
\hline Reef Areas & PMS & Salinity & Temperature & DO & $\mathbf{p H}$ & TA & $\mathbf{S i O}_{2}$ & DIN & DIP \\
\hline \multirow{2}{*}{ Tamandaré } & 45.1 & 40.5 & 29.5 & 133.4 & 8.20 & 2340.9 & 9.40 & 1.63 & 0.15 \\
& $( \pm 3.9)$ & $( \pm 2.1)$ & $( \pm 0.7)$ & $( \pm 7.8)$ & $( \pm 0.07)$ & $( \pm 23.4)$ & $( \pm 4.30)$ & $( \pm 0.21)$ & $( \pm 0.04)$ \\
Serrambi & 33.1 & 38.5 & 29.95 & 153.8 & 8.31 & 2315.7 & 5.38 & 2.80 & 0.22 \\
& $( \pm 6.2)$ & $( \pm 0.7)$ & $( \pm 1.3)$ & $( \pm 33.5)$ & $( \pm 0.11)$ & $( \pm 51.1)$ & $( \pm 1.57)$ & $( \pm 1.56)$ & $( \pm 0.08)$ \\
P. Galinhas & 38 & 37 & 30.15 & 119.4 & 8.22 & 2352.1 & 5.24 & 2.36 & 0.19 \\
& $( \pm 1.4)$ & $( \pm 1.41)$ & $( \pm 1.6)$ & $( \pm 2.6)$ & $( \pm 0.03)$ & $( \pm 0.6)$ & $( \pm 1.38)$ & $( \pm 1.36)$ & $( \pm 0.02)$ \\
Paiva & 46.6 & 38.5 & 29 & 147.5 & 8.40 & 2313.5 & 16.17 & 8.95 & 0.30 \\
& $( \pm 13.3)$ & $( \pm 0.7)$ & $( \pm 1.4)$ & $( \pm 13.2)$ & $( \pm 0.10)$ & $( \pm 29.6)$ & $( \pm 11.98)$ & $( \pm 11.23)$ & $( \pm 0.10)$ \\
R. Doce & 61.2 & 38 & 28 & 140.6 & 8.22 & 2317.0 & 39.39 & 11.68 & 1.03 \\
& $( \pm 37.3)$ & $( \pm 1.4)$ & $( \pm 1.4)$ & $( \pm 24.1)$ & $( \pm 0.05)$ & $( \pm 56.3)$ & $( \pm 11.54)$ & $( \pm 2.77)$ & $( \pm 0.12)$ \\
Piedade & 40.9 & 36 & 27 & 120.5 & 8.30 & 2331.9 & 19.91 & 4.61 & 0.40 \\
& $( \pm 4.9)$ & $( \pm 1.4)$ & $( \pm 1.4)$ & $( \pm 18.7)$ & $( \pm 0.03)$ & $( \pm 7.9)$ & $( \pm 19.08)$ & $( \pm 3.05)$ & $( \pm 0.08)$ \\
\hline
\end{tabular}

In this study, 14 families, 35 genera and 63 species of harpacticoid copepods were registered in the six areas of the study's coastal reefs (Table 2). Of these, only 23 species occurred in both the control and impacted areas. The results indicate that Ectinosoma sp1 was the species with the highest abundance and was found to be present in all collection areas. In the control areas, we observed a greater number of total (55) and exclusive (32) species when compared to impacted areas, where only eight species were found to be exclusive out of 31 total species. Densities (average \pm standard deviation) were very similar for both areas (impacted: $1078 \pm 410$ individuals/ASU; control: $1144 \pm 656$ individuals/ASU).

In the control areas, 12 species were found to have representative relative abundances (relative abundance $\geq 3 \%$ of the total individuals in the area), with Stenhelia sp. (10.75\%), Parastenhelia spinosa $(5.25 \%)$ and Amphiascoides sp1 (5\%) having the highest values. Whereas, in impacted areas, only six species were considered to be representative, with Ectinosoma sp1 (29\%), Ameira sp2 (17\%) and Scutellidium sp. (7.25\%) having the highest values. 
Table 2. List of harpacticoid copepod species identified on the artificial substrates obtained in the control areas (Porto de Galinhas, Serrambi and Tamandaré) and impacted areas (Rio Doce, Piedade, Paiva) in Pernambuco, Brazil, together with percentage contribution of species in each area.

\begin{tabular}{|c|c|c|c|c|c|}
\hline Sub-Order & Family & Genus & Species & Control & Impact \\
\hline Polyarthra & Longipediidae & Longipedia & Longipedia sp. & 1.9 & 1.3 \\
\hline \multirow[t]{62}{*}{ Oligoarthra } & Ameiridae & Ameira & Ameira parvula & 3.4 & 0.0 \\
\hline & & & Ameira sp1 & 5.5 & 0.0 \\
\hline & & & Ameira sp2 & 2.2 & 15.7 \\
\hline & & & Ameira sp3 & 0.5 & 2.9 \\
\hline & & & Ameira sp4 & 0.4 & 0.0 \\
\hline & & Sarsameira & Sarsameira knorri & 0.9 & 0.0 \\
\hline & & & Sarsameira sp1 & 0.0 & 0.4 \\
\hline & & & Sarsameira sp2 & 0.7 & 0.0 \\
\hline & Canthocamptidae & Mesochra & Mesochra sp1 & 0.9 & 0.0 \\
\hline & & & Mesochra sp2 & 0.2 & 1.5 \\
\hline & & & Mesochra sp3 & 0.2 & 0.0 \\
\hline & & Nannomesochra & Nannomesochra sp. & 0.8 & 1.0 \\
\hline & Dactylopusiidae & Dactylopusia & Dactylopusia sp1 & 0.8 & 0.0 \\
\hline & & & Dactylopusia sp2 & 1.9 & 1.9 \\
\hline & & & Dactylopusia tisboides & 3.2 & 5.8 \\
\hline & & Diarthrodes & Diarthrodes sp1 & 0.4 & 0.0 \\
\hline & & & Diarthrodes sp2 & 0.2 & 0.0 \\
\hline & & Paradactylopodia & Paradactylopodia brevicornis & 0.5 & 0.3 \\
\hline & Ectinosomatidae & Ectinosoma & Ectinosoma sp1 & 3.4 & 33.6 \\
\hline & & & Ectinosoma sp2 & 1.8 & 1.9 \\
\hline & & & Ectinosoma sp3 & 0.4 & 0.0 \\
\hline & & Pseudobradya & Pseudobradya sp. & 1.1 & 0.0 \\
\hline & Hamondiidae & Ambunguipes & Ambunguipes sp. & 0.5 & 0.0 \\
\hline & Harpacticidae & Harpacticus & Harpacticus obscurus & 5.6 & 0.0 \\
\hline & & & Harpacticus sp. & 0.0 & 1.4 \\
\hline & Laophontidae & Applanola & Applanola hirsuta & 0.0 & 0.6 \\
\hline & & Echinolaophonte & Echinolaophonte sp. & 0.0 & 0.2 \\
\hline & & Laophonte & Laophonte cornuta & 0.5 & 0.0 \\
\hline & & & Laophonte parvula & 3.9 & 0.0 \\
\hline & & & Laophonte sp1 & 0.2 & 0.0 \\
\hline & & & Laophonte sp2 & 0.0 & 0.2 \\
\hline & & Paralaophonte & Paralaophonte brevirostris & 0.0 & 0.7 \\
\hline & & & Paralaophonte congenera & 1.3 & 0.0 \\
\hline & & & Paralaophonte sp. & 0.0 & 3.9 \\
\hline & Miraciidae & Amonardia & Amonardia sp. & 0.4 & 0.0 \\
\hline & & Amphiascoides & Amphiascoides sp1 & 5.6 & 0.4 \\
\hline & & & Amphiascoides sp2 & 0.7 & 1.5 \\
\hline & & & Amphiascoides sp3 & 0.2 & 0.0 \\
\hline & & Amphiascopsis & Amphiascopsis cinctus & 1.8 & 1.5 \\
\hline & & Amphiascus & Amphiascus (Minutus) sp. & 0.6 & 0.3 \\
\hline & & & Amphiascus (Varians) sp. & 0.4 & 0.0 \\
\hline & & & Amphiascus sp. & 5.3 & 0.0 \\
\hline & & Dactylopodamphiascopsis & Dactylopodamphiascopsis sp. & 0.5 & 0.0 \\
\hline & & Delavalia & Delavalia sp. & 0.5 & 0.0 \\
\hline & & Diosaccus & Diosaccus sp. & 0.5 & 0.0 \\
\hline & & Haloschizopera & Haloschizopera sp. & 0.0 & 0.4 \\
\hline & & Melima & Melima sp1 & 3.2 & 0.8 \\
\hline & & & Melima sp2 & 2.9 & 0.0 \\
\hline & & & Melima sp3 & 0.2 & 0.0 \\
\hline & & Paramphiascella & Paramphiascella sp. & 4.4 & 0.8 \\
\hline & & Robertgurneya & Robertgurneya sp. & 1.4 & 6.2 \\
\hline & & Robertsonia & Robertsonia knoxi & 3.1 & 0.0 \\
\hline & & & Robertsonia mourei & 1.0 & 0.0 \\
\hline & & & Robertsonia sp1 & 0.7 & 0.5 \\
\hline & & & Robertsonia sp2 & 1.4 & 0.9 \\
\hline & & Stenhelia & Stenhelia sp. & 1.3 & 0.0 \\
\hline & Parastenheliidae & Parastenhelia & Parastenhelia spinosa & 13.1 & 0.5 \\
\hline & Peltididae & Alteutha & Alteutha sp. & 3.4 & 0.0 \\
\hline & & Eupelte & Eupelte sp. & 0.5 & 2.4 \\
\hline & Pseudotachidiidae & Xouthous & Xouthous sp. & 1.6 & 2.0 \\
\hline & Thalestridae & Parathalestris & Parathalestris sp. & 0.4 & 0.0 \\
\hline & Tisbidae & Scutellidium & Scutellidium sp. & 1.4 & 8.6 \\
\hline
\end{tabular}


In the comparison between the control and impacted areas, significant differences were found for richness (Pseudo-F $=29.807 ; p<0.001$ ), Margalef diversity (Pseudo-F $=34.268 ; p<0.001$ ), evenness (Pseudo-F $=21.088 ; p=0.003$ ) and Shannon-Wiener diversity (Pseudo-F $=31.486 ; p<0.001$ ). For all of these indexes, the control areas demonstrated higher average values when compared to impacted areas (Figure 2).

The similarity between the replicates in the control and impacted areas can be seen in the NMDS representation (Figure 3). Table 3 shows the results of the SIMPER analysis. Parastenhelia spinosa, Laophonte parvula and Amphiascoides sp1 were the species that contributed most to the control reef similarity, whereas Ectinosoma sp1, Ameira sp2 and Scutellidium sp. were the species that contributed most to impacted reef similarity. The SIMPER average values of similarity between replicates of impacted areas (49.76) were found to be almost twice as large as those between replicates of the control areas (24.44), resulting in significantly different values (Student's $t$-test $=11.49 ; p<0.001$ ). Significant differences were found using a nested PERMANOVA for the comparison between the control and impacted areas, and among reefs within the control and impacted areas (Table 4). The PERMDISP analysis showed significant differences between the reefs included in this study $(\mathrm{F}=5.719 ; p=0.047)$ regarding homogeneity of dispersion, with control reefs showing greater dispersion. This pattern can be seen in the NMDS.

Table 3. Cumulative percentage (Cum. \%) of species contribution to average similarity for the control and impacted areas and dissimilarity between the control and impacted area replicates.

\begin{tabular}{|c|c|c|c|}
\hline Control & & Impact \& Control & \\
\hline Average similarity: 24.44 & & Average dissimilarity $=86.52$ & \\
\hline Species & Cum. \% & Species & Cum. \% \\
\hline Parastenhelia spinosa & 24.38 & Ectinosoma sp1 & 17.47 \\
\hline Laophonte parvula & 31.79 & Ameira sp2 & 26.68 \\
\hline Amphiascoides sp1 & 38.84 & Parastenhelia spinosa & 33.59 \\
\hline Harpacticus obscurus & 45.66 & Scutellidium sp. & 38.16 \\
\hline Paramphiascella sp. & 51.53 & Robertgurneya sp. & 41.66 \\
\hline Robertsonia knoxi & 56.79 & Dactylopusia tisboides & 44.89 \\
\hline Dactylopusia tisboides & 61.13 & Harpacticus obscurus & 47.94 \\
\hline Melima sp1 & 65.33 & Amphiascoides sp1 & 51 \\
\hline Ectinosoma sp1 & 69.4 & Ameira sp1 & 53.99 \\
\hline Amphiascus sp. & 73.37 & Amphiascus sp. & 56.95 \\
\hline Alteutha sp. & 77.09 & Laophonte parvula & 59.55 \\
\hline Ameira sp1 & 79.39 & Alteutha sp. & 61.97 \\
\hline Melima sp2 & 81.61 & Paramphiascella sp. & 64.34 \\
\hline Longipedia sp. & 83.66 & Paralaophonte sp. & 66.36 \\
\hline Ameira parvula & 85.7 & Ameira parvula & 68.34 \\
\hline Amphiascopsis cinctus & 87.49 & Melima sp1 & 70.26 \\
\hline Xouthous sp. & 89.18 & Robertsonia knoxi & 72.08 \\
\hline \multirow[t]{3}{*}{ Ameira sp2 } & 90.71 & Ectinosoma sp2 & 73.75 \\
\hline & & Ameira sp3 & 75.43 \\
\hline & & Dactylopusia sp2 & 77.08 \\
\hline Impact & & Amphiascopsis cinctus & 78.53 \\
\hline \multirow[t]{2}{*}{ Average similarity: 49.76} & & Melima sp2 & 79.98 \\
\hline & & Xouthous sp. & 81.39 \\
\hline Species & Cum. \% & Eupelte sp. & 82.76 \\
\hline Ectinosoma sp1 & 46.21 & Longipedia sp. & 84.07 \\
\hline Ameira sp2 & 69.18 & Robertsonia sp2 & 85.22 \\
\hline Scutellidium sp. & 77.84 & Amphiascoides sp2 & 86.26 \\
\hline Dactylopusia tisboides & 86.2 & Nannomesochra sp. & 87.25 \\
\hline \multirow[t]{4}{*}{ Robertgurneya sp. } & 90.46 & Mesochra sp2 & 88.23 \\
\hline & & Paralaophonte congenera & 89.11 \\
\hline & & Harpacticus sp. & 89.84 \\
\hline & & Stenhelia sp. & 90.53 \\
\hline
\end{tabular}



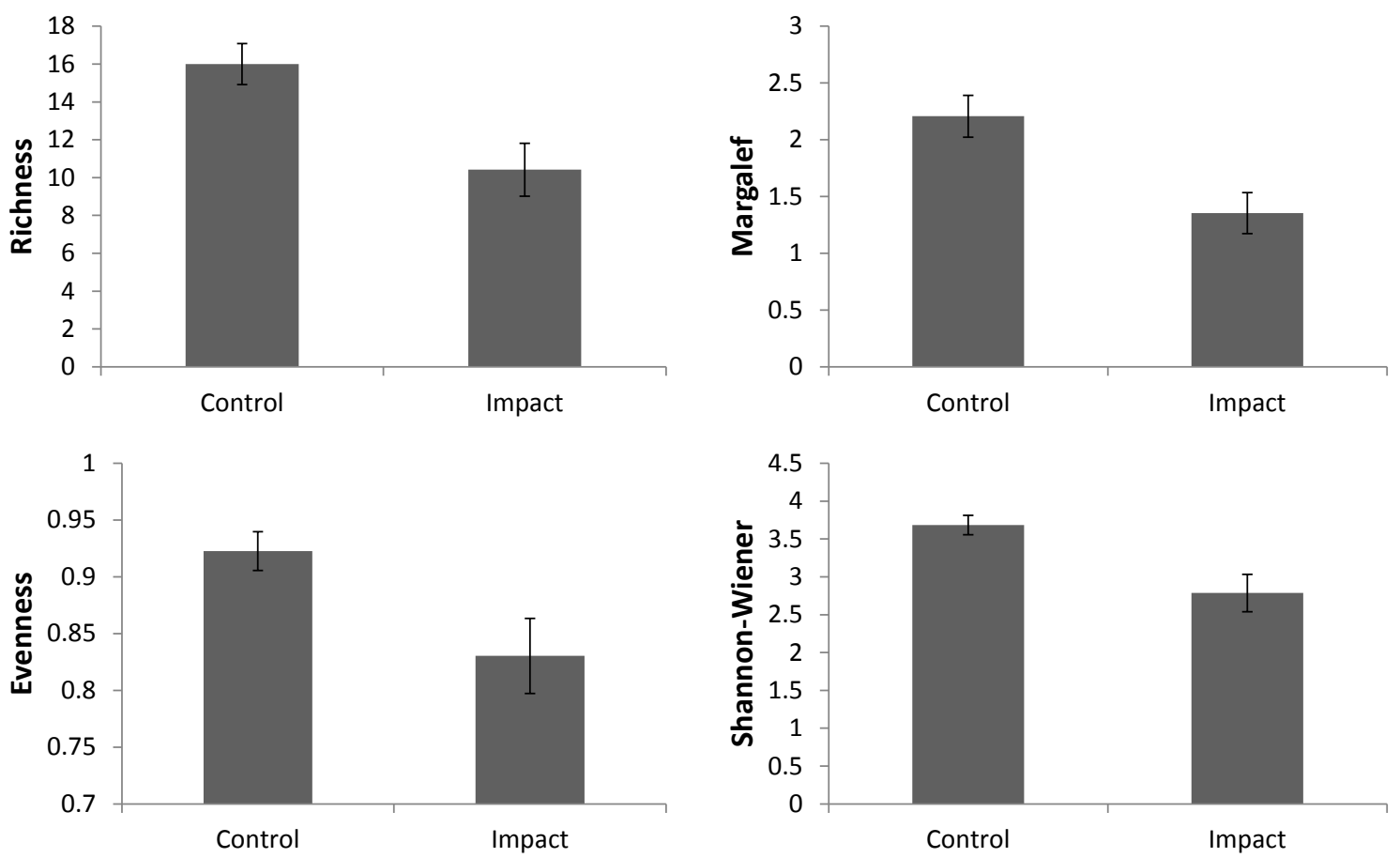

Figure 2. Average values of univariate bioindicators: species richness (S); Margalef diversity index (d); Pielou's evenness index; and Shannon-Wiener diversity index $\left(\mathrm{H}^{\prime}\right)$ in the control and impacted areas, based on the data from the harpacticoid copepods. Bars define confidence intervals of $95 \%$.

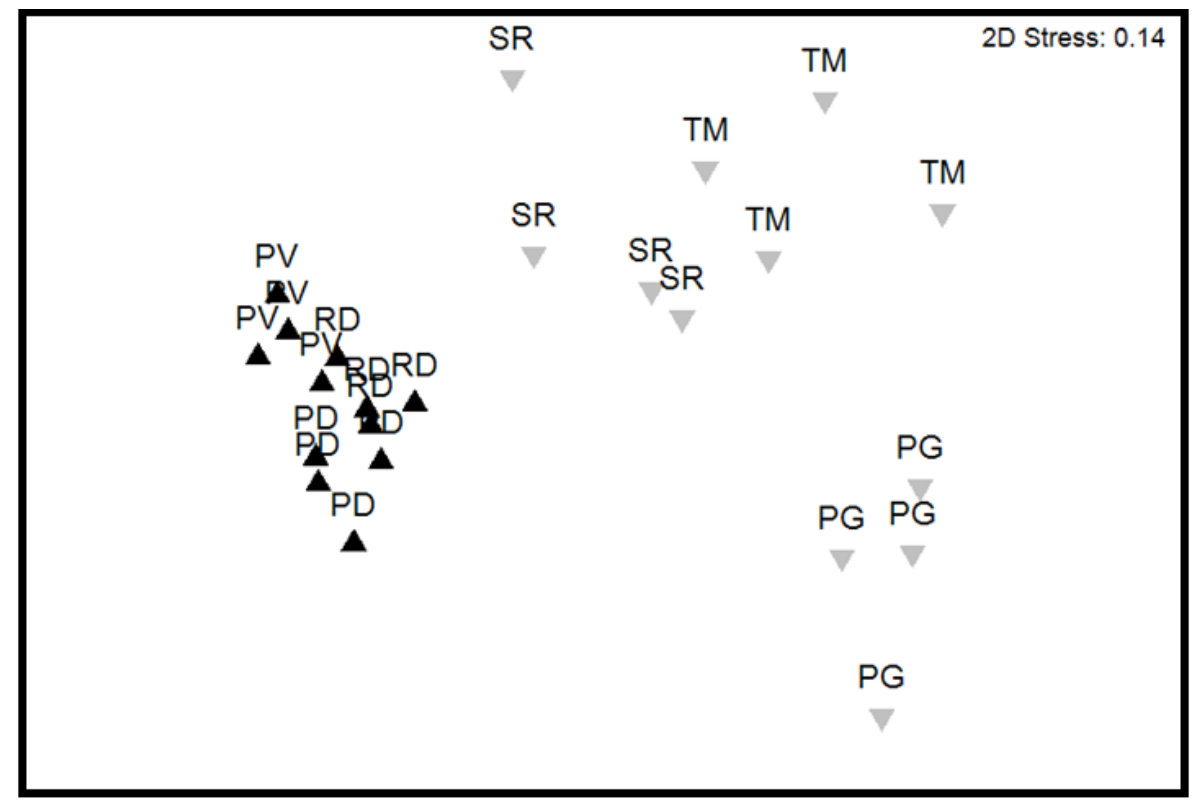

Figure 3. Non-metric multidimensional scaling (NMDS) ordination of Harpacticoida community structure. The control areas are represented by the blue symbols and impacted areas are represented by the green areas. Control areas $(\mathrm{SR}=$ Serrambi, $\mathrm{PG}=$ Porto de Galinhas and $\mathrm{TM}=$ Tamandaré $)$ and impacted areas $(\mathrm{PV}=$ Paiva, $\mathrm{PD}=$ Piedade and $\mathrm{RD}=$ Rio Doce $)$. 
Table 4. The results from the multifactorial PERMANOVA analysis for the structure of the harpacticoid copepod community for factors Impact and Reef (within IMPACT).

\begin{tabular}{cccccc}
\hline Source & Df & SS & MS & Pseudo-F & P (MC) \\
\hline Impact & 1 & 21,768 & 21,768 & 3.6876 & 0.0097 \\
Reef $($ Im) & 4 & 23,612 & 5903 & 4.5396 & 0.0001 \\
Res & 18 & 23,406 & 1300.3 & & \\
Total & 23 & 68,786 & & & \\
\hline
\end{tabular}

The average values of the taxonomic distance indexes for each area can be found in Figure 4. In the comparison of taxonomic distance indexes using a Student's t-test, only the Delta values showed significant differences between the control and impacted areas $(p=0.0291)$. Figure 5 shows the values of Delta+ for each of the sample reefs that were positioned within or very close to the $95 \%$ confidence interval funnel, with no deviations related to anthropogenic impact.
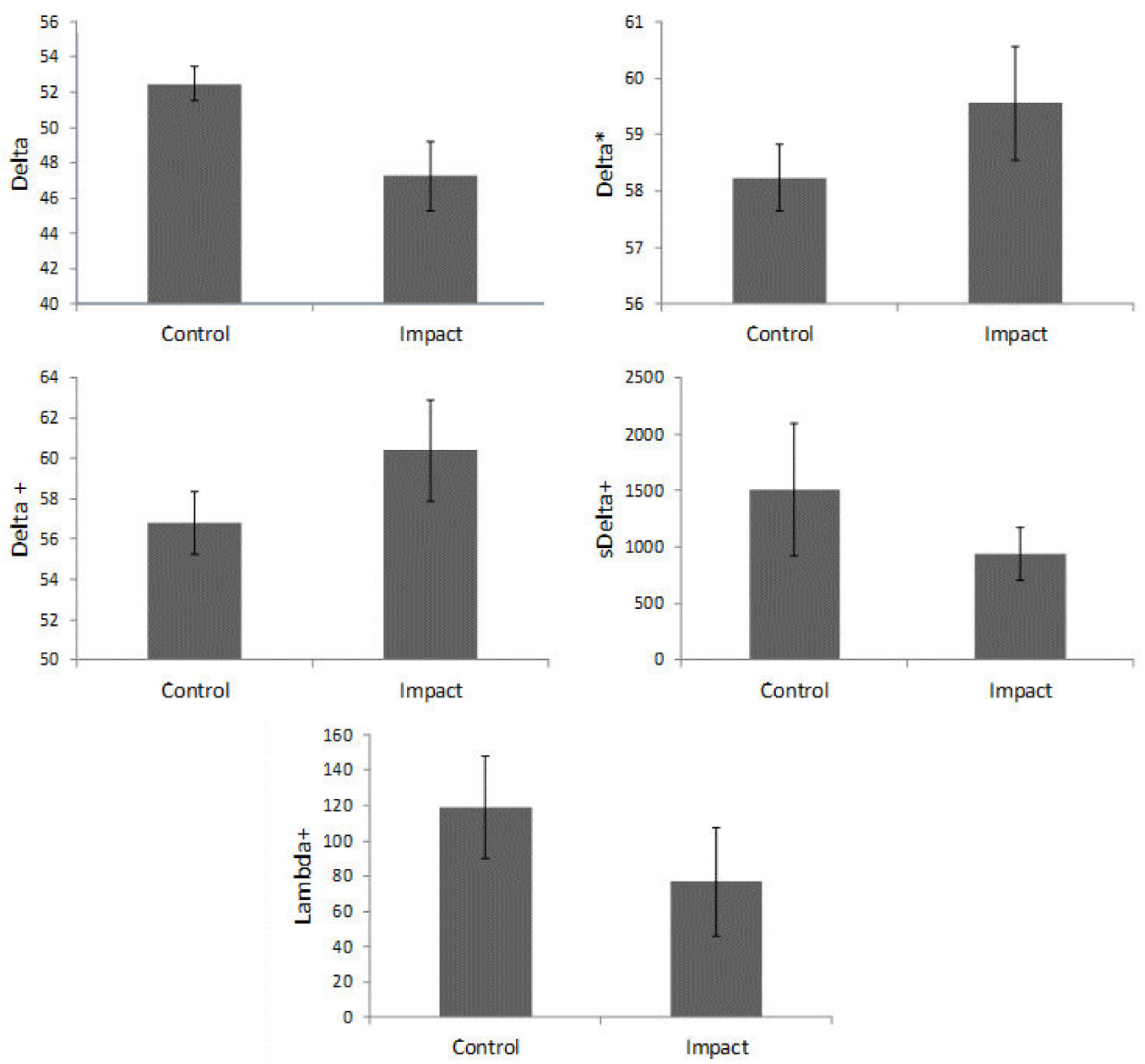

Figure 4. Average values of taxonomic diversity (Delta), taxonomic distance (Delta*), average taxonomic distance (Delta+), variation of taxonomic distance (sDelta+) and total taxonomic distance $($ Lambda + ) for the control and impacted areas. Bars define $95 \%$ confidence intervals. 


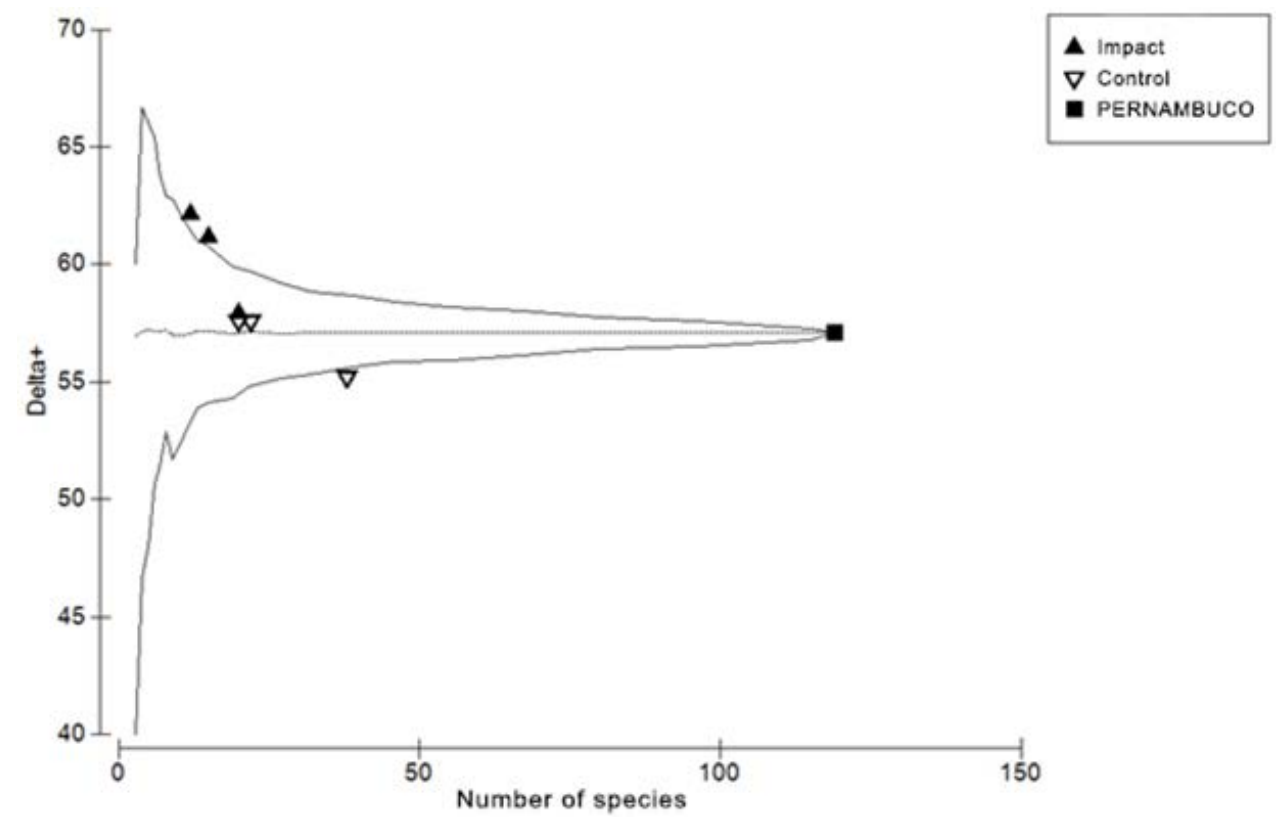

Figure 5. Average taxonomic distance values (Delta+) of six reefs in Pernambuco plotted against the number of species in each area with $95 \%$ confidence limits for random samples of subsets from a species in the regional list.

\section{Discussion}

Environmental variables are fundamental in the comparison and interpretation of meiofauna distribution patterns in areas exposed to different levels of anthropogenic impact [2]. In coral reef ecosystems, the water is generally considered oligotrophic $[60,61]$, supersaturated with oxygen, and the nutrient concentrations are mainly influenced by atmospheric deposition, organic matter remineralization processes, sediment resuspension, or by riverine/estuarine input. The DIN, DIP and $\mathrm{SiO}_{2}$ values registered for the control areas indicated minimal concentrations, which is expected for a non-impacted reef and allows higher levels of diversity [62-65].

However, for the a priori considered impacted areas, the urbanization levels and the consequent run-off of domestic and industrial wastewater are probably the main reasons for the higher nutrient concentrations [63]. The PERMANOVA analysis for nutrients demonstrated relevant differences between the control and impacted areas, supporting the a priori classification of the areas based on their geographical location and/or urbanization.

Despite the high nutrient concentrations in the impacted areas, the oxygen supersaturation due to the intense wave action upon the reefs, together with the high $\mathrm{pH}$ and TA values, indicate that the environments in this study do not suffer from hypoxia and/or coastal water acidification [66].

The synthetic grass ASU used in this study was recently tested in coastal reef environments along the coastline of northeast Brazil $[52,53]$. The results indicated that ASUs made of synthetic grass were an effective representation of the structure of meiofaunal communities in phytal environments in coral reef areas. Across the world, ASUs have been used to monitor the in situ change in biodiversity as a result of different sources of anthropogenic pollution [67], and have been found to be potentially useful as a method of biomonitoring coastal environments [23], a result that is herein supported.

In 1995, Warwick and Clarke [33] found a continuous decrease in the taxonomic distance of a marine community along a gradient of increasing estuarine contamination where species diversity remained constant, indicating a phylogenetic signal of the impact. However, Hall and Greenstreet [36] demonstrated that in demersal fish communities, TDIs (taxonomic distance indexes) exhibited the same behaviors as conventional diversity indexes when comparing disturbance levels in this environment. Somerfield et al. [68] also concluded that it was not possible to consistently observe 
the decreasing pattern of TDI values for macrofauna, and found an increased impact in deeper regions. Thus, Salas et al. [55] tested the robustness of taxonomic distinction measures. They applied them to different scenarios of estuarine disturbance in Portugal and Spain and found that in the majority of case studies, among the various TDIs used, only the total index of taxonomic distinction was relatively satisfactory in discriminating situations of disturbance and contrast with the used indexes (Shannon-Wiener, Margalef and eco-exergy). In the present study, the classic indexes of ecological diversity clearly characterize the differences between the control and impacted areas. However, the taxonomic distinction measures, with the exception of the taxonomic diversity (Delta) index, did not show clear signs of impact differentiation, a finding which has been previously found in several of the case studies cited above (e.g., References $[36,55,68]$ ). These results suggest that the strong loss of harpacticoid copepod species in coastal reefs under the impact of multistressors does not present a significant phylogenetic signal.

The diversity indexes calculated for coral reef harpacticoid copepods (Margalef, evenness and Shannon-Wiener diversity) were found to be significantly greater in the control areas when compared to impacted areas. Furthermore, the community structure of harpacticoid copepods was also found to be highly sensitive to differences between the control and impacted areas based on PERMANOVA results. Mirto and Danovaro [23] found greater taxon richness in a meiofaunal community in control areas compared to impacted areas when investigating the dynamic colonization of meiofauna at the level of large taxonomic groups on artificial substrates made of nylon brushes in the port of Ancona, in the north of the Adriatic Sea. Other studies, using classic indexes, also found that anthropogenic stressors, such as fishing activities [69,70], mechanical disturbances [71], sedimentation increase [72], species invasions [73], temperature increase [74] and water pollution [75] had negative effects on reef environments. These stressors led to a decrease in richness and/or diversity of coral communities. Anthropogenic disturbances may create spatial and temporal variability in community structures in terrestrial, aquatic, and marine ecosystems [76,77]. Currently, the rate at which environmental conditions are changing introduces the concern of ecosystems becoming simplified, with less spatial variability [78], especially in extremely diverse tropical ecosystems, such as coastal coral reefs [79]. Our results indicate that changes in environments caused by anthropogenic multistressors cause the simplification of coral reef harpacticoid copepod communities, resulting in greater homogeneity within and between impacted areas and control areas. Similar results were found for benthic communities under the impact of seawater acidification $[80,81]$.

In several previously studied areas, the simplification of communities driven by anthropogenic impacts has raised questions on how the diversity of an ecosystem influences its function. Recent studies affirmed that a greater number of species can lead to greater temporal stability of an ecosystem [82]. More than $50 \%$ of species identified in this study were exclusively present in the control areas, suggesting that this notable difference may be due to the reduction in harpacticoid copepod richness and could potentially affect the function of this ecosystem in impacted areas, a theme that deserves further attention.

In the control areas, the species with the highest densities were Stenhelia sp., Parastenhelia spinosa and Amphiascoides sp. The species that were found exclusively in the control area reefs were Parastenhelia spinosa, Amphiascus sp., Laophonte paroula, Harpacticus obscurus, Ameira sp. and Ameira parvula. In a study on the direct impact of human trampling in a reef area on the coast of Pernambuco, Sarmento and Santos [31] also verified that Parastenhelia spinosa and Ameira parvula were some of the most abundant species in a protected area [8]. Furthermore, Amphiascus sp. (the same species as in the present study) was found to be one of the species found exclusively in the protected areas [31]. In this way, we conclude that environmental changes caused by anthropogenic multistressors cause the simplification of meiofaunal communities and the homogenization of ecosystems in impacted areas through decreases in richness. Furthermore, we can conclude that indicators based on taxonomic distinction are less efficient than classic indicators in the detection of anthropogenic impacts on harpacticoid copepod associations in coastal reef environments, since these impacts did not present a strong phylogenetic signal. 
Author Contributions: P.J.P.S. conceived and outlined the study. M.S.B., B.J.d.S. and P.J.P.S. conducted the field experiment implantation and removal. M.S.B., B.J.d.S. and M.J.F.M. conducted chemical and biological analysis. M.S.B. and P.J.P.S. were responsible for data analysis and interpretation. M.S.B., B.J.d.S. and P.J.P.S. wrote the article.

Funding: This research was funded by Conselho Nacional de Ciência e Tecnologia (CNPq) grant number 306444/2014-3.

Acknowledgments: MS Barroso (IBPG-0077-2.04/15) gratefully acknowledges a graduate scholarship from Fundação de Amparo à Ciência e Tecnologia do Estado de Pernambuco (FACEPE) and PJP Santos (CNPq 306444/2014-3) acknowledges research grants from Conselho Nacional de Ciência e Tecnologia (CNPq). Special thanks are due to three anonymous referees whose suggestions improved the manuscript and to Rebecca N. Umeed for assistance with English language.

Conflicts of Interest: The authors declare no conflict of interest.

\section{References}

1. Loreau, M.; Naeem, S.; Inchausti, P.; Bengtsson, J.; Grime, J.P.; Hector, A.; Hooper, A.; Huston, M.A.; Raffaelli, D.; Schmid, B.; et al. Biodiversity and ecosystem functioning: Current knowledge and future challenges. Science 2001, 294, 804-808. [CrossRef] [PubMed]

2. Zeppilli, D.; Sarrazin, J.; Leduc, D.; Arbizu, P.M.; Fontaneto, D.; Fontanier, C.; Gooday, A.J.; Kristensen, R.M.; Ivanenko, V.N.; Sørensen, M.V.; et al. Is the meiofauna a good indicator for climate change and anthropogenic impacts? Mar. Biodiv. 2015, 45, 505-535. [CrossRef]

3. Borja, A.; Muxika, I. Do benthic indicator tools respond to all impact sources? The case of AMBI (AZTI Marine Biotic Index). In Proceedings of the Workshop Indicators of Stress in the Marine Benthos, Torregrande-Oristano, Italy, 8-9 October 2004; Magni, P., Hyland, J., Manzella, G., Rumohr, H., Viaroli, P., Zenetos, A., Eds.; Intergovernmental Oceanographic Commission: Paris, France, 2005; pp. 15-18.

4. Leao, Z.M.; Kikuchi, R.K. A relic coral fauna threatened by global changes and human activities, Eastern Brazil. Mar. Pollut. Bull. 2005, 51, 599-611. [CrossRef] [PubMed]

5. Defeo, O.; Rueda, M. Spatial structure, sampling design and abundance estimates in sandy beach macroinfauna: Some warnings and new perspectives. Mar. Biol. 2002, 140, 1215-1225. [CrossRef]

6. Van Andel, T.H. Science at Sea: Tales of an Old Ocean; W.H. Freeman \& Co. Ltd.: San Francisco, CA, USA, 1981; ISBN 9780716713647.

7. Gingold, R.; Moens, T.; Rocha-Olivares, A. Assessing the Response of Nematode Communities to Climate Change-Driven Warming: A Microcosm Experiment. PLoS ONE 2013, 8, e66653. [CrossRef] [PubMed]

8. Hoegh-Guldberg, O.; Mumby, P.J.; Hooten, A.J.; Steneck, R.S.; Greenfield, P.; Gomez, E.; Harvell, C.D.; Sale, P.F.; Edwards, A.J.; Caldeira, K.; et al. Coral reefs under rapid climate change and ocean acidification. Science 2007, 318, 1737-1742. [CrossRef] [PubMed]

9. Sarmento, V.C.; Souza, T.P.; Esteves, A.M.; Santos, P.J.P. Effects of seawater acidification on a coral reef meiofauna community. Coral Reefs 2015, 34, 955-966. [CrossRef]

10. Valença, A.P.M.; Santos, P.J. Macrobenthic community for assessment of estuarine health in tropical areas (Northeast, Brazil): Review of macrofauna classification in ecological groups and application of AZTI Marine Biotic Index. Mar. Pollut. Bull. 2012, 64, 1809-1820. [CrossRef] [PubMed]

11. Myers, N. Mass extinction and evolution. Science 1997, 278, 597-598. [CrossRef]

12. Baskin, Y. Winners and losers in a changing world. BioScience 1998, 48, 788-792. [CrossRef]

13. Fabricius, K.E.; Langdon, C.; Uthicke, S.; Humphrey, C.; Noonan, S.; De'ath, G.; Lough, J.M. Losers and winners in coral reefs acclimatized to elevated carbon dioxide concentrations. Nat. Clim. Chang. 2011, 1, 165-169. [CrossRef]

14. Tabarelli, M.; Carlos, A.P.; Felipe, P.L.M. The 'few winners and many losers' paradigm revisited: Emerging prospects for tropical forest biodiversity. Biol. Conserv. 2012, 155, 136-140. [CrossRef]

15. McKinney, M.L.; Lockwood, J.L. Biotic homogenization: A few winners replacing many losers in the next mass extinction. Trends Ecol. Evol. 1999, 14, 450-453. [CrossRef]

16. Leão, Z.M.N.; Dominguez, J.M.L. Tropical coast of Brazil. Mar. Pollut. Bull. 2000, 41, 112-122. [CrossRef]

17. Ferreira, M.N.; Rosso, S. Effects of human trampling on a rocky shore fauna on the Sao Paulo coast, southeastern Brazil. Braz. J. Biol. 2009, 69, 993-999. [CrossRef] [PubMed]

18. Leão, Z.M.N.; Kikuchi, R.K.P.; Oliveira, M.D.M.; Vasconcellos, V. Status of Eastern Brazilian coral reefs in time of climate changes. Pan-Am. J. Aquat. Sci. 2011, 5, 224-235. 
19. Moberg, F.; Folke, C. Ecological goods and services of coral reef ecosystems. Ecol. Econ. 1999, 29, $215-233$. [CrossRef]

20. Dunning, K.H. Ecosystem services and community based coral reef management institutions in post blast-fishing Indonesia. Ecosyst. Serv. 2015 16, 319-332.

21. Sarmento, V.C.; Barreto, A.F.; Santos, P.J. The response of meiofauna to human trampling on coral reefs. Sci. Mar. 2011, 75, 559-570. [CrossRef]

22. Leão, Z.M.; Kikuchi, R.K.; Ferreira, B.P.; Neves, E.G.; Sovierzoski, H.H.; Oliveira, M.D.; Maida, M.; Correia, M.D.; Johnsson, R. Brazilian coral reefs in a period of global change: A synthesis. Braz. J. Oceanogr. 2016, 64, 97-116. [CrossRef]

23. Mirto, S.; Danovaro, R. Meiofaunal colonisation on artificial substrates: A tool for biomonitoring the environmental quality on coastal marine systems. Mar. Pollut. Bull. 2004, 48, 919-926. [CrossRef] [PubMed]

24. Bishop, M.J. Artificial sampling units: A tool for increasing the sensitivity of tests for impact in soft sediments. Environ. Monit. Assess. 2005, 107, 203-220. [CrossRef] [PubMed]

25. De Troch, M.; Vandepitte, L.M.; Raes, M.; Suárez-Morales, E.; Vincx, M. A field colonization experiment with meiofauna and seagrass mimics: Effect of time, distance and leaf surface area. Mar. Biol. 2005, 148, 73-86. [CrossRef]

26. Rule, M.J.; Smith, S.D.A. Depth-associated patterns in the development of benthic assemblages on artificial substrata deployed on shallow, subtropical reefs. J. Exp. Mar. Biol. Ecol. 2007, 345, 38-51. [CrossRef]

27. Hicks, G.R.; Geoffrey, R.F.; Bruce, C. The ecology of marine meiobenthic harpacticoid copepods. Oceanogr. Mar. Biol. Anu. Rev. 1983, 21, 67-175.

28. Coull, B.C. Ecology of the marine meiofauna. In Introduction to the Study of Meiofauna; Higgins, R.P., Thiel, H., Eds.; Smithsonian Institution Press: Washington, DC, USA, 1988; Volume 132, pp. 18-38. ISBN 0-87474-488-1.

29. Danovaro, R.; Scopa, M.; Gambi, C.; Franschetti, S. Trophic importance of subtidal metazoan meiofauna: Evidence from in situ exclusion experiments on soft and rocky substrates. Mar. Biol. 2007, 152, 339-350. [CrossRef]

30. Danovaro, R.; Corinaldesi, C.; Dell'Anno, A.; Snelgrove, P.V.R. The deep-sea under global change. Curr. Biol. 2017, 27, 461-465. [CrossRef] [PubMed]

31. Sarmento, V.C.; Santos, P.J.P. Trampling on coral reefs: Tourism effects on harpacticoid copepods. Coral Reefs 2012, 31, 135-146. [CrossRef]

32. Costa, A.B.H.P.; Valença, A.P.M.C.; Santos, P.J.P. Is meiofauna community structure in Artificial Substrate Units a good tool to assess anthropogenic impact in estuaries? Mar. Poll. Bull. 2016, 110, 354-361. [CrossRef] [PubMed]

33. Warwick, R.M.; Clarke, K.R. New “biodiversity" measures reveal a decrease in taxonomic distinctness with increasing stress. Mar. Ecol. Prog. Ser. 1995, 129, 301-305. [CrossRef]

34. Piepenburg, D.; Voss, J.; Gutt, J. Assemblages of sea stars (Echinodermata: Asteroidea) and brittle stars (Echinodermata: Ophiuroidea) in the Weddell Sea (Antarctica) and off Northeast Greenland (Arctic): A comparison of diversity and abundance. Polar Biol. 1997, 17, 305-322. [CrossRef]

35. Clarke, K.R.; Warwick, R.M. A taxonomic distinctness index and its statistical properties. J. Appl. Ecol. 1998, 35, 523-531. [CrossRef]

36. Hall, S.J.; Greenstreet, S.P. Taxonomic distinctness and diversity measures: Responses in marine fish communities. Mar. Ecol. Prog. Ser. 1998, 166, 227-229. [CrossRef]

37. Price, N.N.; Hamilton, S.L.; Tootell, J.S.; Smith, J.E. Species-specific consequences of ocean acidification for the calcareous tropical green algae Halimeda. Mar. Ecol. Prog. Ser. 2011, 440, 67-78. [CrossRef]

38. Rogers, S.I.; Clarke, K.R.; Reynolds, J.D. The taxonomic distinctness of costal bottom-dweling fish communities of the North East Atlantic. J. Anim. Ecol. 1999, 68, 769-788. [CrossRef]

39. Warwick, R.M.; Light, J. Death assemblages of molluscs on St Martin's Flats, Isles of Scilly: A surrogate for regional biodiversity? Biodiv. Conserv. 2002, 11, 99-112. [CrossRef]

40. Warwick, R.M.; Turk, S.M. Predicting climate change effects on marine biodiversity: Comparison of recent and fossil molluscan death assemblages. J. Mar. Biol. Assoc. UK 2002, 82, 847-850. [CrossRef]

41. Warwick, R.M.; Ashman, C.M.; Brown, A.R.; Clarke, K.R.; Dowell, B.; Hart, B.; Lewis, R.E.; Shillabeer, N.; Somerfield, P.J.; Tapp, J.F. Inter-annual changes in the biodiversity and community structure of the macrobenthos in Tees Bay and the Tees estuary, UK, associated with local and regional environmental events. Mar. Ecol. Progr. Ser. 2002, 234, 1-13. [CrossRef] 
42. Grasshoff, K.; Ehrhardt, M.; Kremling, K. Methods of Seawater Analysis, 2nd ed.; Verlag Chemie: New York, NY, USA, 1983; 419p, ISBN 3527259988.

43. Strickland, J.D.; Parsons, T.R. A Practical Handbook of Seawater Analysis; Bulletin 167; Fisheries Research Board of Canada: Ottawa, Canada, 1972.

44. United Nations Educational, Scientific and Cultural Organization (UNESCO). International Oceanographic Table. Wormly 1973, 2, 1-141.

45. Dickson, A.G.; Sabine, C.L.; Christian, J.R. Guide to Best Practices for Ocean $\mathrm{CO}_{2}$ Measurements; PICES Special Publication; North Pacific Marine Science Organization: Sidney, BC, Canada, 2007; Volume 3, pp. 1-191. ISBN 1897176074.

46. Sarmento, V.C.; Pinheiro, B.R.; Montes, M.J.F.; Santos, P.J.P. Impact of predicted climate change scenarios on a coral reef meiofauna community. ICES J. Mar. Sci. 2017, 74, 1170-1179. [CrossRef]

47. Santos, P.J.P.; Castel, J.; Souza-Santos, L.P. Development time of harpacticoid copepods: Some empirical models and implications. J. Mar. Biol. Assoc. UK 1999, 79, 1123-1124. [CrossRef]

48. Sarmento, V.C.; Santos, P.J.P.; Hale, R.; Ingels, J.; Widdicombe, S. Effects of elevated $\mathrm{CO}_{2}$ and temperature on an intertidal harpacticoid copepod community. ICES J. Mar. Sci. 2017, 74, 1159-1169.

49. Lang, K. Monographie der Harpacticiden; Nordiska Bökhandeln: Stockholm, Sweden, 1948; pp. 1-1648. ISBN 3874290891, 9783874290890.

50. Huys, R.; Gee, J.M.; Moore, C.G.; Hamond, R. Marine and brackish water harpacticoid Copepods. Part 1: Keys and notes for identification of the species. In Synopses of the British Fauna (New Series) no. 51; Barnes, R.S.K., Crothers, J.H., Eds.; Field Studies Council: Shrewsbury, UK, 1996; pp. 1-352. ISBN 978-1851532568.

51. Wells, J.B.J. An annotated checklist and keys to the species of Copepoda Harpacticoida (Crustacea). Zootaxa 2007, 1568, 1-872.

52. Barreto, A.F. Viability of ASU (Artificial Substrate Unit) in the Evaluation of Anthropic Pressure over the Assemblages of Meiofauna and Copepoda Harpacticoida in Reef Environments. Master's Thesis, Universidade Federal de Pernambuco, Recife, Brazil, 2014. (In Portuguese)

53. Nascimento, R.F.M. Temporal Variation of Phytal Meiofauna and Copepoda Harpacticoida Communities in a Climate Change Scenario. Master's Thesis, Universidade Federal de Pernambuco, Recife, Brazil, 2015. (In Portuguese)

54. Clarke, K.R.; Warwick, R.M. A further biodiversity index applicable to species lists: Variation in taxonomic distinctness. Mar. Ecol. Prog. Ser. 2001, 216, 265-278. [CrossRef]

55. Salas, F.; Marcosa, C.; Neto, J.M.; Patrício, J.; Pérez-Ruzafa, A.; Marques, J.C. User friendly guide for using benthic ecological indicators in coastal and marine quality assessment. Ocean Coast. Manag. 2006, 49, 308-331. [CrossRef]

56. Anderson, M.J. A new method for non-parametric multivariate analysis of variance. Austral Ecol. 2001, 26, 32-46. [CrossRef]

57. McArdle, B.H.; Anderson, M.J. Fitting multivariate models to community data: A comment on distance based redundancy analysis. Ecology 2001, 82, 290-297. [CrossRef]

58. Clarke, K.R.; Warwick, R.M. Change in Marine Communities: An Approach to Statistical Analysis and Interpretation; Natural Environment Research Council (NERC): Plymouth, UK, 1994; pp. 1-187. ISBN 9781855311404.

59. Zar, J.H. Biostatistical Analysis, 3rd ed.; Prentice-Hall: Upper Saddle River, NJ, USA, 1996; pp. 1-662. ISBN 9780130845429.

60. Bastos, R.B. Caracterização de uma zona costeira tropical (Ipojuca-Pernambuco-Brasil): Produtividade fitoplanctônica e outras variáveis ambientais. Braz. J. Aquat. Sci. Technol. 2011, 15, 1-10. [CrossRef]

61. Machado, R.C.A. Phytoplankton productivity and hydrology of Porto de Galinhas reef ecosystem (Pernambuco, Brazil). J. Coast. Res. 2013, 30, 371-378. [CrossRef]

62. Grego, C.K.S.; Feitosa, F.A.N.; Silva, M.H.; Flores-Montes, M.J. Distribuição espacial e sazonal da clorofila-a fitoplanctônica e hidrologia do estuário do rio Timbó (Paulista, PE). Trop. Oceanogr. 2004, 32, 181-199. [CrossRef]

63. Jales, M.C.; Feitosa, F.A.N.; Koening, M.L.; Bastos, R.B.; Machado, R.C.A. O Ecossistema Recifal de Serrambi (Nordeste Do Brasil): Biomassa Fitoplanctônica e Parâmetros Hidrológicos. Atlântica 2012, 34, 87-102. [CrossRef]

64. Maranhão, G.M.B.; Fonseca-Genevois, V.; Passavante, J.Z.O. Meiofauna da área recifal da Baía de Tamandaré (Pernambuco, Brasil). Trop. Oceanog. UFPE 2000, 28, 47-59. [CrossRef] 
65. Da Rocha, C.M.C.; Venekey, V.; Bezerra, T.N.C.; Souza, J.R.B. Phytal marine nematode assenblages and their relation with the macrophytes structural complexity in a Brazilian tropical rocky beach. Hydrobiologia 2006, 533, 210-230. [CrossRef]

66. Cai, W.J.; Hu, X.; Huang, W.J.; Murrell, M.C.; Lehrter, J.C.; Lohrenz, S.E.; Zhao, P. Acidification of subsurface coastal waters enhanced by eutrophication. Nat. Geosci. 2011, 4, 766-770. [CrossRef]

67. Czerniawska-Kusza, I. Use of artificial substrates for sampling benthic macroinvertebrates in the assessment of water quality of large lowland rivers. Pol. J. Environ. Stud. 2004, 13, 579-584.

68. Somerfield, P.J.; Olsgard, F.; Carr, M.R. A further examination of two new taxonomic distinctness measures. Mar. Ecol. Progr. Ser. 1997, 154, 303-306. [CrossRef]

69. Bavestrello, G.; Cerrano, C.; Zanzi, D.; Cattaneo-Vietti, R. Damage by fishing activities to the Gorgonian coral Paramuricea clavata in the Ligurian Sea. Aquat. Conserv. Mar. Freshw. Ecosyst. 2007, 7, 253-262. [CrossRef]

70. Tsounis, G.; Rossi, S.; Gili, J.M.; Arntz, W. Red coral fishery at the Costa Brava (NW Mediterranean): Case study of an overharvested precious coral. Ecosystems 2007, 10, 975-986. [CrossRef]

71. Coma, R.; Pola, E.; Ribes, M.; Zabala, M. Long-term assessment of temperate octocoral mortality patterns, protected vs. unprotected areas. Ecol. Appl. 2004, 14, 1466-1478. [CrossRef]

72. Balata, D.; Piazzi, L.; Cecchi, E.; Cinelli, F. Variability of Mediterranean coralligenous assemblages subject to local variation in sediment deposition. Mar. Environ. Res. 2005, 60, 403-421. [CrossRef] [PubMed]

73. Baldacconi, R.; Corriero, G. Effects of the spread of the alga Caulerpa racemosa var. Cylindracea on the sponge assemblage from coralligenous concretions of the Apulian coast (Ionian Sea, Italy). Mar. Ecol. 2009, 30, 337-345. [CrossRef]

74. Garrabou, J.; Perez, T.; Sartoretto, S.; Harmelin, J.G. Mass mortality event in red coral Corallium rubrum populations in the Provence region (France, NW Mediterranean). Mar. Ecol. Progr. Ser. 2001, 217, $263-272$. [CrossRef]

75. Giuliani, S.; Lamberti, C.V.; Sonni, C.; Pellegrini, D. Mucilage impact on gorgonians in the Tyrrhenian Sea. Sci. Total Environ. 2005, 353, 340-349. [CrossRef] [PubMed]

76. Sousa, W.P. Experimental investigations of disturbance and ecological succession in a rocky intertidal algal community. Ecol. Monogr. 1979, 49, 227-254. [CrossRef]

77. Whited, D.C.; Lorang, M.S.; Harner, M.J.; Hauer, F.R.; Kimball, J.S.; Stanford, J.A. Climate, hydrologic disturbance, and succession: Drivers of floodplain pattern. Ecology 2007, 88, 940-953. [CrossRef] [PubMed]

78. Jackson, J.B. Ecological extinction and evolution in the brave new ocean. Proc. Nat. Acad. Sci. USA 2008, 105, 11458-11465. [CrossRef] [PubMed]

79. Foley, J.A.; DeFries, R.; Asner, G.P.; Barford, C.; Bonan, G.; Carpenter, S.R.; Chapin, F.S.; Coe, M.T.; Daily, G.C.; Gibbs, H.K.; et al. Global consequences of land use. Science 2005, 309, 570-574. [CrossRef] [PubMed]

80. Kroeker, K.J.; Gambi, M.-C.; Micheli, F. Community dynamics and ecosystem simplification in a high-CO ocean. Proc. Nat. Acad. Sci. USA 2013, 110, 12721-12726. [CrossRef] [PubMed]

81. Brown, N.E.; Milazzo, M.; Rastrick, S.P.; Hall-Spencer, J.M.; Therriault, T.W.; Harley, C.G. Natural acidification changes the timing and rate of succession, alters community structure, and increases homogeneity in marine biofouling communities. Glob. Chang. Biol. 2017, 24, e112-e127. [CrossRef] [PubMed]

82. Tilman, D.; Reich, P.B.; Knops, J.M. Biodiversity and ecosystem stability in a decade-long grassland experiment. Nature 2006, 441, 629-632. [CrossRef] [PubMed]

(C) 2018 by the authors. Licensee MDPI, Basel, Switzerland. This article is an open access article distributed under the terms and conditions of the Creative Commons Attribution (CC BY) license (http://creativecommons.org/licenses/by/4.0/). 